\title{
NABYCIE WŁASNOŚCI GRUNTU POKRYTEGO WODAMI
}

\section{ACQUISITION OF TITLE TO LAND UNDER WATER}

\section{STRESZCZENIE}

Celem artykułu jest przedstawienie problematyki nabycia własności gruntu pokrytego wodami jako instytucji prawa polskiego. W szczególności przedmiot oceny stanowi zagadnienie wpływu zmiany stanu wód w przyrodzie na kształtowanie się nabywania gruntu pokrytego wodami, a także analiza wszystkich innych zdarzeń prawnych, których skutkiem będzie nabycie prawa własności gruntu pokrytego wodami.

Prof. dr hab. z zakresu prawa ochrony środowiska; Kierownik Katedry Prawa Ochrony Środowiska WPiA UMK w Toruniu; profesor UKW w Bydgoszczy; radca prawny. 


\section{Słowa kluczowe} wód.

Gospodarowanie wodami; grunt pokryty wodami; własność

\section{ABSTRACT}

The aim of the article is to present the issue of acquisition of title to land under water as a legal institution of the Polish law. In particular, there is a need to tackle the question of the consequences of the change in the status of water in nature for the acquisition of title to land under water. There is also a matter of consequences of other legal situations for the acquisition of such a title.

\section{Keywords}

Water management; land under water; ownership of waters.

W systemie prawa polskiego ustawodawca konsekwentnie oddziela własność wód od własności gruntów pod wodami. Specyficzny charakter ma jedynie własność wód i choć ustawodawca używa pojęcia własność, to jednak nie jest to własność w rozumieniu prawa cywilnego. Specyficzna własność wód jest ściśle powiązana z własnością gruntu pod wodami i choć ten związek ma bardzo ścisły charakter, to jednak własność wód jest traktowana odrębnie od własności gruntów pod wodami, czy też odwrotnie, własność gruntów pod wodami jest traktowana odrębnie od własności gruntu ${ }^{1}$.

Prawodawca polski regulując ów związek normatywny pomiędzy własnością wód i własnością gruntów pod wodami, odwołuje się do dwóch zasad. Pierwsza dotyczy powierzchniowych wód płynących i według niej właściciel wód jest też właścicielem gruntu pod wodami. Natomiast druga zasada dotyczy powierzchniowych wód stojących i polega na tym, że właściciel

1 Pogląd ten jest już ugruntowany w piśmiennictwie. Zob. m.in. A. Agopszowicza, Własność wód, jej istota $i$ charakter prawny, ZNUJ 1974, z. 1; S.M. Grzybowskiego, Zagadnienia cywilistyczne prawa wodnego, Warszawa 1957; czy S. Rudnickiego, O własności wód, NP 1982, nr 11-12, s. 78. 
gruntu jest rónież właścicielem wód. Ów silny związek normatywny pomiędzy własnością wód i własnością gruntu pod wodami pociąga za sobą określone skutki prawne. W zasadzie więź ta ma charakter stały i stabilny, niemniej jednak mogą zaistnieć takie sytuacje, które będą tę więź dopiero kreowały lub zmieniały, a nawet likwidowały. Taką sytuacją jest nabywanie własności gruntów pokrytych wodami.

Celem tego artykułu jest analiza, w jaki sposób zmiany stanu wód w przyrodzie mogą wpływać na kształtowanie się nabywania gruntu pokrytego wodami, a także analiza wszystkich innych zdarzeń prawnych, których skutkiem będzie nabycie prawa własności gruntu pokrytego wodami. Oczywiście na plan pierwszy wysuwa się sytuacja związana z wystąpieniem wody z brzegów lub zmianą jej biegu, niemniej jednak w tym zdarzeniu prawnym nie wyczerpuje się całość zagadnień związanych z nabyciem własności gruntów pod wodami. Ustawodawca definiuje pojęcie „grunt pokryty wodami”. Jak stanowi art. 9 pkt 4a ustawy z dnia 18 lipca 2001 r. Prawo wodne ${ }^{2}$ „rozumie się przez to grunty tworzące dna i brzegi cieków naturalnych, jezior oraz innych naturalnych zbiorników wodnych, w granicach linii brzegu, a także grunty wchodzące w skład sztucznych zbiorników wodnych, stopni wodnych oraz jezior podpiętrzonych, będące gruntami pokrytymi wodami powierzchniowymi przed wykonaniem urządzeń piętrzących". Tylko tak zdefiniowane grunty będą przedmiotem dalszej analizy. Poza rozważaniami będą kwestie związane z własnością innych gruntów.

Zasadą obowiązującą $\mathrm{w}$ polskim prawie wodnym jest zasada, iż grunty pokryte powierzchniowymi wodami płynącymi są wyłączone z obrotu cywilnoprawnego, chyba że ustawa stanowi inaczej. Wynika to wprost z art. 10 ustawy z dnia 18 lipca 2001 roku Prawo wodne, stanowiącego, że

„1. Wody stanowią własność Skarbu Państwa, innych osób prawnych albo osób fizycznych.

1a. Wody morza terytorialnego, morskie wody wewnętrzne wraz z morskimi wodami wewnętrznymi Zatoki Gdańskiej, śródlądowe wody powierzchniowe płynące

2 Tj. Dz.U. z 2015 r., poz. 469, dalej cyt.: Prawo wodne. 
oraz wody podziemne stanowią własność Skarbu Państwa.

2. Wody stanowiące własność Skarbu Państwa lub jednostek samorządu terytorialnego są wodami publicznymi.

3. Płynące wody publiczne nie podlegają obrotowi cywilnoprawnemu, $\mathrm{z}$ wyjątkiem przypadków określonych w ustawie".

J. Szachułowicz wskazał, iż „przez obrót cywilnoprawny rozumiane jest nie tylko wyzbycie się prawa własności, ale także obciążenie tego prawa inną formą prawną prowadzącą do korzystania z cudzej rzeczy"3. Uwaga ta jest w pełni trafna, choć z badanego punktu widzenia wskazanie, że chodzi o czynności prawne powodujące skutek w postaci przejścia prawa własności, jest najistotniejsze. W konsekwencji przez obrót cywilnoprawny należy rozumieć tutaj czynności prawne, których skutkiem jest zmiana właściciela. Jednak pojęcie obrotu prawnego nie obejmuje innych zdarzeń prawnych, które nie są czynnościami prawnymi. W teorii prawa powszechnie uznaje się, że zdarzenie prawne to pewien fakt występujący w świecie niezależnie od woli i od zachowań ludzi, z którym normy prawne wiążą określone konsekwencje ${ }^{4}$. Wskazuje się, że „zdarzeniem prawnym jest też [...] zmiana koryta rzeki będącej granicą dwóch państw" . Jednak prawodawca polski wiąże skutek w zakresie zmiany właściciela gruntu pokrytego wodami także od zdarzeń prawnych.

Tym samym prawodawca dopuszcza możliwość nabywania własności gruntów pokrytych wodami w inny sposób niż poprzez czynności prawne. Podkreślić jednak trzeba, że i wyłączenie gruntów pokrytych wodami z obrotu cywilnoprawnego nie ma charakteru bezwzględnego, gdyż prawodawca dopuszcza możliwość przenoszenia własności $\mathrm{w}$ drodze czynności prawnej, ale tylko w sytuacji, gdy ustawa wyraźnie tak stanowi. Nie jest więc dopuszczalne domniemanie możliwości przeniesienia

3 J. Szachułowicz, Prawo wodne. Komentarz, Warszawa 2010, s. 63.

4 S. Wronkowska, Podstawowe pojęcia prawa i prawoznawstwa, Poznań 2005, s. 177.

5 Ibidem, s. 177. 
własności gruntu pokrytego wodami, gdyż taka możliwość musi wprost wynikać z ustawy.

Konsekwencją wyłączenia gruntów pokrytych wodami z obrotu prawnego jest to, że wzrasta ranga i znaczenie innych zdarzeń prawnych, które mogą doprowadzić do skutku polegającego na nabyciu własności gruntu.

W myśl art. 16 Prawa wodnego

„1. Właściciel wody nie nabywa praw do gruntów zalanych przez wodę podczas powodzi.

2. Właścicielowi gruntów zalanych podczas powodzi nie przysługuje z tego tytułu odszkodowanie od właściciela wody.

3. Właścicielowi gruntów zalanych podczas powodzi w wyniku nieprzestrzegania przepisów ustawy przez właściciela wody lub właściciela urządzenia wodnego przysługuje odszkodowanie na warunkach określonych w ustawie.

4. Właścicielowi posiadającemu grunty leżące w granicach polderu przeciwpowodziowego, zalanego podczas powodzi, przysługuje od właściciela wody odszkodowanie na warunkach określonych w ustawie".

W art. 16 Prawa wodnego została uregulowana zasada, iż właściciel wód nie nabywa prawa do własności gruntów, które zostały zalane wodami w konsekwencji powodzi. Dalsza część tego przepisu koncentruje się na ewentualnych kwestiach roszczeń odszkodowawczych, niemniej jednak powódź, jako zdarzenie prawne, nie spowoduje skutku $\mathrm{w}$ postaci nabycia prawa własności gruntów pod wodami. O tym, że art. 16 Prawa wodnego wyraża zasadę, decyduje hipoteza normy prawnej6. Przepis jest bowiem adresowany do każdego właściciela wody. Ów generalnie określony zakres podmiotowy rozstrzyga o tym, że art. 16 ma postać normy ogólnej. Zwrócić jednak należy uwagę, że ustawodawca ogranicza zakres przedmiotowy obszaru re-

6 Trzeba jednak zauważyć, że sam art. 16 Prawa wodnego stanowi wyjątek od zasady przyjętej w art. 14 tejże ustawy, na co słusznie zwraca uwagę M. Kałużny, Prawo wodne. Komentarz, Warszawa 2012, s. 101. 
gulacji normy prawnej, gdyż wskazuje tylko na jedno zdarzenie prawne, jakim jest powódź.

Pojęcie powodzi należy rozumieć tak, jak ustawodawca definiuje je w art. 9 pkt 10 Prawa wodnego. Według tego przepisu powódź „to czasowe pokrycie przez wodę terenu, który w normalnych warunkach nie jest pokryty wodą, wywołane przez wezbranie wody w ciekach naturalnych, zbiornikach wodnych, kanałach oraz od strony morza, z wyłączeniem pokrycia przez wodę terenu wywołanego przez wezbranie wody w systemach kanalizacyjnych".

Jednak rodzi się pytanie, jakie skutki prawne powstaną w przypadku, gdy dojdzie do wystąpienia wody z brzegów, ale przyczyną takiego wystąpienia nie będzie powódź. Na tak postawione pytanie należy mimo wszystko udzielić odpowiedzi negatywnej i stwierdzić, że wystąpienie wody z brzegów z innych przyczyn niż powódź, również nie spowoduje skutku w postaci nabycia prawa własności gruntu pokrytego wodami przez właściciela tych wód. Wniosek taki należy sformułować, uwzględniając art. 12 ust. 1 Prawa wodnego, z którego wynika, że wody stojące są przedmiotem własności tego, kto jest właścicielem gruntu. Zatem w przypadku, gdy woda wystąpi z brzegów z innych przyczyn niż powódź, stanie się przedmiotem własności tego, kto jest właścicielem gruntu z powołaniem się na art. 12 ust. 1 Prawa wodnego. Skoro zatem nie ma znaczenia przyczyna wystąpienia wód z brzegów, rodzi się pytanie o racjonalność wymienienia w art. 16 tylko takiej sytuacji, którą należy zakwalifikować jako powódź.

Racjonalność działania prawodawcy tym bardziej trzeba podać w wątpliwość, jeśli uwzględni się okoliczności wskazane $\mathrm{w}$ art. 17 Prawa wodnego. Zgodnie z tym przepisem

„1. Jeżeli śródlądowa woda powierzchniowa płynąca lub wody morza terytorialnego albo morskie wody wewnętrzne zajmą trwale, w sposób naturalny, grunt niestanowiący własności właściciela wody, grunt ten staje się własnością właściciela wody.

2. W przypadku, o którym mowa w ust. 1, dotychczasowemu właścicielowi gruntu przysługuje odszkodowanie od właściciela wody na warunkach określonych w ustawie". 
Na wyjątkowy charakter artykułu 17 Prawa wodnego wskazuje zakres przedmiotowy. W odróżnieniu od art. 16 Prawa wodnego ustawodawca nie zdecydował się na bezpośrednie określenie zakresu podmiotowego i nie wskazał, że przepis ten dotyczy właściciela określonych kategorii wód. Można jedynie wnioskować o adresacie normy prawnej z zakresu przedmiotowego. Skoro w ustawie wymieniono określone rodzaje wód, to adresatem art. 17 Prawa wodnego będą te podmioty, które są właścicielami wymienionych w tym przepisie wód. W każdym przypadku będzie to Skarb Państwa.

Zwrócić jednak należy uwagę, że prawodawca w art. 17 Prawa wodnego wymienił szczegółowo i enumeratywnie poszczególne rodzaje wód. Z takiego ukształtowania normy prawnej można i należy wyprowadzić wniosek, iż jest to przepis szczególny w stosunku do art. 16. Argument ten ulega wzmocnieniu również przez to, że artykuł regulujący, kiedy dojdzie do nabycia prawa własności gruntu pokrytego wodami w sytuacji, gdy woda wystąpiła z brzegów, jest umieszczony po przepisie wskazującym, iż właściciel wody (in genere) nie nabywa własności gruntów pokrytych wodami.

Rozwiązanie przyjęte w art. 17 Prawa wodnego ma również swoje uzasadnienie w mechanizmie rządzącym związkiem własności wód z własnością gruntów pokrytych wodami. Wskazywany już wcześniej art. 14 ust. 1 Prawa wodnego wskazuje na regułę, iż kto jest właścicielem wody, jest właścicielem gruntów pod tymi wodami. Widać więc tutaj wyraźnie, iż własność gruntu pokrytego wodami jest pochodna i zależna od własności wód. Jednak z tej normy prawnej, która taką regułę określa, wynika również wprost, że dotyczy to jedynie śródlądowych powierzchniowych wód płynących.

Z kolei związku między pozostałymi wodami a gruntem pokrytym tymi wodami dotyczy art. 12 ust. 1 Prawa wodnego. Statuuje on zasadę, że kto jest właścicielem gruntu, jest też właścicielem wód. Zestawienie chociażby tylko tych dwóch norm prawnych pozwala na przyjęcie wniosku, że powierzchniowe wody płynące są przez ustawodawcę traktowane wyjątkowo. Wyjątek ten przejawia się chociażby w przyjęciu zasady, czyjego woda, tego grunt, jak również w przyjęciu mechanizmu nabycia 
prawa własności gruntu pokrytego powierzchniowymi wodami płynącymi. Zatem rozwiązanie przyjęte w art. 17 Prawa wodnego jest logiczną konsekwencją statutu, jaki prawodawca nadaje śródlądowym powierzchniowym wodom płynącym.

Zastosowanie art. 17 Prawa wodnego uzależnione jest jednak od spełnienia określonych przesłanek. W konsekwencji, nabycie gruntu pokrytego wodami przez właściciela wód powierzchniowych, wymienionych w ust. 1 , nie ma charakteru bezwarunkowego.

Artykuł 17 ust. 1 Prawa wodnego określa dwie przesłanki. Pierwszą przesłanką jest przesłanka zajęcia gruntu w sposób naturalny, drugą przesłanką jest przesłanka, aby to zajęcie miało charakter trwały. Konstrukcja tego przepisu wskazuje, że obie przesłanki muszą być spełnione łącznie, a nabycie własności gruntu zajętego przez te wody następuje z mocy samego prawa. Takie też stanowisko zajęło orzecznictwo, a przykładem niech będzie wyrok WSA w Krakowie z dnia 21 stycznia 2009, sygn. II SA/Kr 794/087: „zgodnie z treścią art. 17 ust. 2 p.w. gdy w związku z trwałym zajęciem gruntu przez wodę płynącą następuje utrata własności, to grunt trwale zalany, w sposób naturalny, przez powierzchniowe wody śródlądowe staje się własnością właściciela wody, a więc z mocy samego prawa (ex lege), natomiast chociaż utrata własności następuje za odszkodowaniem od właściciela wody na warunkach określonych w art. 188 p.w., to w kwestii odszkodowania musi się toczyć odrębne postępowanie".

Pierwsza przesłanka jest przesłanką określoną przez ustawodawcę jako zajęcie gruntu w sposób naturalny. Przesłanka ta jest nader enigmatyczna, tym bardziej jeśli zestawić ją z wcześniej analizowanym już art. 16 Prawa wodnego, w którym prawodawca posłużył się sformułowaniem powódź. Biorąc pod uwagę dyrektywę wykładni, iż na te same zjawiska i sytuacje ustawodawca używa tych samych sformułowań, a na różne zjawiska i sytuacje używa różnych sformułowań, należy stwierdzić, że w art. 16 i art. 17 chodzi o różne sytuacje. 
Wobec legalnej definicji pojęcia powódź, art. 16 nie budzi wątpliwości, natomiast takowe pojawiają się w związku z użyciem sformułowania „w sposób naturalny”. Wykładnia celowościowa tego przepisu prowadzi do wniosku, że chodzi tutaj o zajęcie gruntów z przyczyn mających swoje umocowanie wyłącznie w działaniach sił natury. M. Kałużny wskazał, iż naturalność zajęcia gruntu oznacza „wszystkie zdarzenia, których źródło tkwi w działaniu przyrody. Wykluczyć należy zatem czyny człowieka (np. zajęcie gruntu podczas regulacji koryt cieków). Takie zajęcie [tj. zależne od czynu człowieka - przyp. B.R.] jest naruszeniem własności, które powinno zostać uregulowane w postępowaniu cywilnym pomiędzy właścicielem zajętego gruntu a podmiotem, który dokonał naruszenia lub jest za to odpowiedzialny na mocy umów lub przepisów prawa"8.

Prawodawca wyklucza zatem przyczyny, które w jakikolwiek sposób zostały zainicjowane, czy wręcz wywołane działaniem lub zaniechaniem człowieka. Przepis ten znajdzie zastosowanie tylko wtedy, jeżeli wyłączną i jedyną przyczyną zajęcia gruntu przez te wody będą siły naturalne. Należałoby raczej zaakcentować nie tyle samo działanie natury ${ }^{9}$, ile niezależność tych przyczyn od działania lub zaniechania człowieka. Istotą bowiem tej przesłanki jest uniezależnienie skutku określonego w tym przepisie od działań lub zaniechań człowieka. Trzeba mieć bowiem na względzie, że art. 17 ust. 1 Prawa wodnego pociąga za sobą daleko idące skutki, gdyż pozbawia właściciela gruntu zajętego przez te wody prawa własności. Dochodzi więc tutaj do utraty prawa własności na rzecz podmiotu publicznego, którym zawsze będzie Skarb Państwa ${ }^{10}$.

8 M. Kałużny, op.cit., s. 109.

9 Por. J. Szachułowicz, op.cit., s. 96.

10 Odmiennie W. Radecki, [w:] J. Rotko (red.), Prawo wodne. Komentarz, Wrocław 2002, s. 74, który uważa, że w grę wchodzi także nabycie prawa własności także na rzecz jednostek samorządu terytorialnego. Wprawdzie z brzemienia art. 17 ust. 1 Prawa wodnego nie wynika, że chodzi o powierzchniowe wody płynące. Trudno jednak przyjąć, iż racjonalnie działający prawodawca regułę, czyja woda, tego grunt, zastosował w tej sytuacji także do wód stojących, gdyż tylko takie wody mogą być przedmiotem własności jednostek samorządu terytorialnego. 
Gdyby więc ustawodawca uzależniał skutek w postaci utraty prawa własności od zachowania człowieka, prowokowałby w ten sposób do takich zachowań, które powodowałyby utratę prawa własności. Rozwiązanie przyjęte w art. 17 ust. 1 Prawa wodnego należy raczej widzieć jako reakcję prawodawcy na niepożądany przez niego skutek i wynik działania sił natury. Nie może on pozostawać obojętny wobec sytuacji, które w praktyce występują i musi zachować się racjonalnie wobec takich przypadków. Musi też konsekwentnie stosować zasadę przyjętą w art. 14 - czyjego własność wód, tego własność gruntu.

Jednym z pierwszych przykładów zajęcia przez wody gruntów w sposób naturalny jest właśnie powódź. Skoro jednak prawodawca nie wskazuje w art. 17 ust. 1 Prawa wodnego na powódź, a posługuje się pojęciem bardziej ogólnym - „sposób naturalny", musi mieć na myśli również i inne okoliczności niż tylko powódź. Sformułowanie „w sposób naturalny” obejmuje zarówno powódź, jak i inne zjawiska, których skutkiem będzie zajęcie przez wody gruntów, będących przedmiotem własności innych podmiotów niż właściciel wody.

Artykuł 17 ust. 1 Prawa wodnego nie wymaga, aby owo zajęcie w sposób naturalny miało pierwotnie charakter zdarzenia gwałtownego, a wręcz odwrotnie, używając sformułowania „trwałe zajęcie”, ma bardziej na myśli sytuację następującą łagodnie i rozłożoną w czasie. W art. 17 Prawa wodnego ustawodawca nie uzależnia również skutku w postaci nabycia prawa własności gruntu od winy określonego podmiotu, jak również od zaniedbania wykonywania obowiązków prawem określonych.

Drugą przesłanką, od zaistnienia której uzależniony jest skutek w postaci nabycia prawa własności gruntu pokrytego wodami, wymienioną $\mathrm{w}$ art. 17 ust. 1 Prawa wodnego, jest trwałość zajęcia przez te wody tego gruntu. Choć przesłanka ta jest nieco bardziej precyzyjna, to jednak budzi nie mniejsze wątpliwości niż pierwsza, wyżej przeanalizowana. M. Kałużny zdefiniował trwałe zajęcie jako „nie tylko zniszczenie wierzchniej warstwy gleby, ale także fizyczne, trwałe pokrycie gruntu przez wodę. Bardzo często podczas przepływu wód powodziowych zdarza się, że zdegradowaniu ulegnie warstwa orna grun- 
tu (wymycie, naniesienie materiału skalnego). Taki stan rzeczy nie jest tożsamy z naturalnym zajęciem gruntu. Aby można było mówić o zajęciu gruntu przez wodę, musi się ona na nim znajdować również przy normalnych (najczęściej występujących) stanach"11.

Pojęcie trwałości zajęcia wprowadza do konstrukcji art. 17 element temporalny. Ustawodawca polski zna rozwiązania polegające na tym, że skutek prawny w postaci nabycia własności następuje $\mathrm{w}$ związku z upływem określonego czasu. W teorii prawa cywilnego konstrukcję taką kwalifikuje się jako dawność, przy czym w stosunku do prawa własności nieruchomości chodzi konkretnie o zasiedzenie. Pojęcie dawności obejmuje instytucje (zdarzenia prawne), które wiążą nastąpienie skutków prawnych z upływem czasu ${ }^{12}$. Problem znaczenia czynnika temporalnego w kontekście utraty prawa własności na rzecz samoistnego posiadacza był przedmiotem zainteresowania piśmiennictwa z zakresu prawa cywilnego ${ }^{13}$. Wskazywano przede wszystkim, że istotą zasiedzenia jest bierna postawa właściciela wobec swojej nieruchomości i zaniechanie wykonywania prawa własności.

Z uwagi na potrzeby ochrony pewności obrotu prawnego ustawodawca polski uznał, że niewykonywanie prawa własności w określonym czasie musi wywołać skutek polegający na utracie tego prawa. Niemniej jednak instytucja zasiedzenia stoi w opozycji do konstytucyjnej zasady ochrony własności. Jest to dopuszczalne ograniczenie, czy wręcz pozbawienie prawa własności, niemniej jednak wobec tej instytucji, konstytucyjnie poprawnej, ustawodawca zwykły musi zachować szczególną staranność z punktu widzenia ochrony praw i wolności jednostki.

Jedną z gwarancji ochrony praw i wolności jednostki jest to, że w art. 172 kodeksu cywilnego prawodawca dokładnie

11 M. Kałużny, op.cit., s. 103-104.

12 U. Ernst, A. Rachwał, F. Zoll, Prawo cywilne. Część ogólna, Warszawa 2013, s. 265.

13 Por. chociażby opracowania podręcznikowe J. Ignatowicz, K. Stefaniuk, Prawo rzeczowe, , Warszawa 2012; E. Gniewek, Prawo rzeczowe, Warszawa 2008; B. Ziemianin, K. A. Dadańska, Prawo rzeczowe, Warszawa 2012. 
wskazał, jaki okres jest konieczny do wywołania skutku w postaci utraty prawa własności. Biorąc pod uwagę tę okoliczność, właściciel gruntu wie, że jeżeli nie zapobieże samoistnemu posiadaniu nieruchomości w okresie lat 20, to utraci prawo własności. Prawodawca jednak dokładnie określa mu termin, w jakim może podjąć skuteczną obronę swojego prawa.

Tymczasem w przypadku art. 17 ust. 1 Prawa wodnego, ten element gwarancyjny nie został zachowany, co pozwala na sformułowanie wątpliwości, czy art. 17 ust. 1 Prawa wodnego jest zgodny z Konstytucją Rzeczypospolitej Polskiej z dnia 2 kwietnia 1997 r., a przede wszystkim art. 64 i 31 ust. 3, a także art. 21.

Użyte w art. 17 ust. 1 Prawa wodnego sformułowanie „trwałe zajęcie” ma przede wszystkim cechę niedookreśloności. Nie można bowiem w żadem sposób ustalić precyzyjnie co do dnia, kiedy można już mówić o trwałym zajęciu gruntu. Skoro prawodawca zdecydował się na sformułowanie takiej przesłanki, to znaczy, że nie dojdzie do nabycia własności gruntu, jeżeli zajęcie przez wodę nie miało charakteru trwałego. Jeśli jednak, na co wskazywano wyżej, a w doktrynie nie jest sporne, skutek w postaci nabycia prawa własności gruntu następuje z mocy ustawy, to zasada pewności obrotu prawnego wymaga, aby precyzyjnie określić, $\mathrm{w}$ jakim terminie nastąpi skutek w postaci z jednej strony utraty prawa własności, a z drugiej nabycia. De lege ferenda konieczne jest, aby wskazać, w jakim dokładnie momencie nastąpiło przejście prawa własności gruntu. Zapewne kwestia ta będzie rozstrzygana $\mathrm{w}$ postępowaniu o odszkodowanie, o którym mowa w art. 17 ust. 2 Prawa wodnego. W przypadku gdy zajęcie nie ma jeszcze charakteru trwałego, to roszczenie odszkodowawcze będzie co najmniej przedwczesne.

Analizując pojęcie „trwałego zajęcia”, należy mieć na względzie cel art. 17 ust. 1 Prawa wodnego. Ustawodawca akceptując sytuację polegającą na tym, że doszło do zajęcia gruntu przez wody wskazane w art. 17 ust. 1 Prawa wodnego, godzi się z zaistniałym stanem faktycznym i dostosowuje status prawny gruntu do istniejącego stanu faktycznego. Chce bowiem uniknąć sytuacji, iż kto inny jest właścicielem wody, a kto inny jest właścicielem gruntu pokrytego wodami, choć należy zaznaczyć, 1/2015 że taki dualizm i tak będzie występował aż do momentu, kiedy 
zostanie spełniona przesłanka trwałości zajęcia. W tym też kontekście należy postrzegać przesłankę trwałości zajęcia w aspekcie możliwego cofnięcia się wód z tego gruntu, czy to w wyniku działania sił przyrody, czy to w wyniku aktywności człowieka. Jeżeli dojdzie do cofnięcia lub cofnięcia się wody, art. 17 ust. 1 nie będzie miał zastosowania.

Powstaje pytanie, w jaki sposób właściciel gruntu może podjąć obronę swojego prawa własności, skoro skutek w postaci utraty własności następuje z mocy prawa. Wydaje się, że oprócz powództwa z art. 189 kodeksu cywilnego właściciel może wykorzystać również postępowanie z art. 15 Prawa wodnego. Określanie linii brzegowej wymusi na organie administracji publicznej dokonanie oceny, czy skutek w postaci trwałego zajęcia już wystąpił, czy też nie.

Wskazane wyżej reguły nabywania własności gruntów pokrytych wodami nie dotyczą wód stojących. Jest to zresztą konsekwencja przyjętej w stosunku do wód stojących zasady, iż kto jest właścicielem gruntu, jest właścicielem wód. Skoro zatem wody stojące dzielą los i byt prawny gruntu pod tymi wodami, to trudno oczekiwać od racjonalnie działającego prawodawcy, aby stosowanie tej zasady wyłączył przy nabywaniu własności.

Istotną okolicznością jest to, że w przypadkach określonych w art. 10 Prawa wodnego grunty pokryte wodami są wyłączone z obrotu prawnego, chyba że ustawa stanowi inaczej. Jednak reguła ta, wyłączająca określone rodzaje gruntu pokrytego wodami z obrotu cywilnoprawnego, nie dotyczy gruntów pokrytych wodami stojącymi.

Wobec braku wyraźnego wyłączenia tych gruntów z obrotu cywilnoprawnego zastosowanie będzie miała zasada, iż grunty te mogą być przedmiotem obrotu cywilnoprawnego. Skoro tak, to będą one mogły być przedmiotem obrotu cywilnoprawnego, jak każda inna nieruchomość gruntowa. Prawo własności wód stojących będzie przechodziło na tego, kto jest właścicielem gruntów, które te wody pokrywają.

Podsumowując, wskazać należy, że obrót cywilnoprawny gruntami pokrytymi wodami jest wyłączony. Jest on możliwy wtedy, gdy wyraźnie tak stanowi ustawa. Obrót cywilnoprawny polega na dokonywaniu czynności prawnych, których skutkiem 
będzie nabycie prawa własności (przejście) z jednego podmiotu na drugi. Polskie Prawo wodne takiej możliwości nie przyjmuje za zasadę, a jedynie za wyjątek. Wobec tego rodzi się konieczność poszukiwania innych sytuacji (zdarzeń prawnych), których efektem byłoby nabycie prawa własności gruntów pokrytych wodami. Sytuację taką reguluje art. 17 Prawa wodnego, który dopuszcza nabycie własności takiego gruntu pokrytego wodami, ale jedynie gdy woda powierzchniowa publiczna zajęła taki grunt w sposób trwały i naturalny. Obie te przesłanki budzą wątpliwości, przy czym za najważniejszą należy uznać brak wyraźnie określonego momentu przejścia tego prawa na właściciela wód. Jest to poważny mankament z punktu widzenia zasady bezpieczeństwa obrotu prawnego. De lege ferenda zasadne jest uregulowanie tej kwestii w ustawie. Obecnie ustalenie, czy taki skutek wystąpił, musi być badane w ewentualnych postępowaniach o ustalenie, o ustalenie linii brzegowej, czy wreszcie w postępowaniu o odszkodowanie.

\section{BIBLIOGRAFIA}

Agopszowicz A., Wtasność wód, jej istota i charakter prawny, ZNUJ 1974, z. 1.

Ernst U., Rachwał A., Zoll F., Prawo cywilne. Czesść ogólna, Warszawa 2013.

Gniewek E., Prawo rzeczowe, Warszawa 2008.

Grzybowski S. M., Zagadnienia cywilistyczne prawa wodnego, Warszawa 1957.

Ignatowicz J., Stefaniuk K., Prawo rzeczowe, Warszawa 2012.

Kałużny M., Prawo wodne. Komentarz, Warszawa 2012.

Prawo wodne. Komentarz, pod red. J. Rotki, Wrocław 2002.

Rudnicki S., O własności wód, NP 1982, Nr 11-12.

Szachułowicz J., Prawo wodne. Komentarz, Warszawa 2010.

Wronkowska S., Podstawowe pojęcia prawa i prawoznawstwa, Poznań 2005.

Ziemianin B., Dadańska K. A., Prawo rzeczowe, Warszawa 2012.

Kontakt e-mail:

kpos@umk.pl 